\title{
The chronic consumption of milk proteins improve vascular function and lipid biomarkers in mildly hypertensive adults: results from the Whey2Go RCT
}

\author{
Á.A. Fekete ${ }^{1,2}$, C. Giromini ${ }^{3}$, Y. Chatzidiakou ${ }^{1}$, I.D. Givens ${ }^{2}$ and J.A. Lovegrove ${ }^{1}$ \\ ${ }^{1}$ Hugh Sinclair Unit of Human Nutrition, University of Reading, United Kingdom, ${ }^{2}$ Food Production and Quality \\ Research Division, University of Reading, United Kingdom and ${ }^{3}$ Department of Health, Animal Science and Food \\ Safety, University of Milan, 20134 Milan, Italy
}

Cardiovascular diseases are the major cause of death in the world and their reduction is a key public health target ${ }^{(1)}$. Epidemiological studies have shown that milk consumption has beneficial impacts on the cardiovascular system ${ }^{(2)}$. The aim of this study was to investigate if intact dairy proteins can improve vascular function in mildly hypertensive adults. This was an 8-wk double-blinded, randomised, cross-over, controlled intervention study. Forty-two participants were randomised to consume $2 \times 28 \mathrm{~g}$ of whey protein, Ca-caseinate and $2 \times 27 \mathrm{~g}$ maltodextrin (control) daily. A linear mixed-model ANOVA was used to assess the impacts of the interventions. Thirty-eight participants completed the study. We found significant reductions in peripheral and central systolic pressure $(-5.7 \mathrm{mmHg}, \mathrm{p}=0.007 ;-5.4 \mathrm{mmHg}, \mathrm{p}=0.012$, respectively) and mean pressure $(-3.7 \mathrm{mmHg}, \mathrm{p}=0.025 ;-4.0 \mathrm{mmHg}, \mathrm{p}=0.019, \mathrm{re}-$ spectively) assessed by pulse wave analysis after whey protein supplementation compared with control. Flow-mediated dilation increased significantly after both whey protein and Ca-caseinate compared with control $(1.31 \%, \mathrm{p}<0.001$, and $0 \cdot 83 \%, \mathrm{p}=0 \cdot 003$, respectively). Both whey protein and Ca-caseinate significantly reduced total cholesterol $(-0.26 \mathrm{mmol} / \mathrm{L}, \mathrm{p}=0.013 ;-0.20 \mathrm{mmol} / \mathrm{L}, \mathrm{p}=$ 0.042 , respectively), however only whey protein decreased triacylglycerol $(-0.23 \mathrm{mmol} / \mathrm{L}, \mathrm{p}=0.025)$ too, compared with control. Adhesion molecules were also lowered: sICAM-1 and sVCAM-1 were reduced after whey protein $(p=0.011)$ and Ca-caseinate consumption $(\mathrm{p}=0.039)$ compared with control, respectively. The 8-week consumption of intact milk proteins resulted in improvements in vascular reactivity, biomarkers of endothelial function and lipid risk factors with greater benefit after whey protein supplementation. This may have important implications for public health. This trial was registered at clinicaltrials.gov as NCT02090842.

1. Gasser SP, Selwyn AP, Ganz P. (1996) Am Heart J. 131 (2):379-84.

2. Elwood PC, Pickering JE, Givens DI, et al. (2010) Lipids. 45 (10):925-39. 